\title{
What kind of power can build society? A remarkable power play in Susanna
}

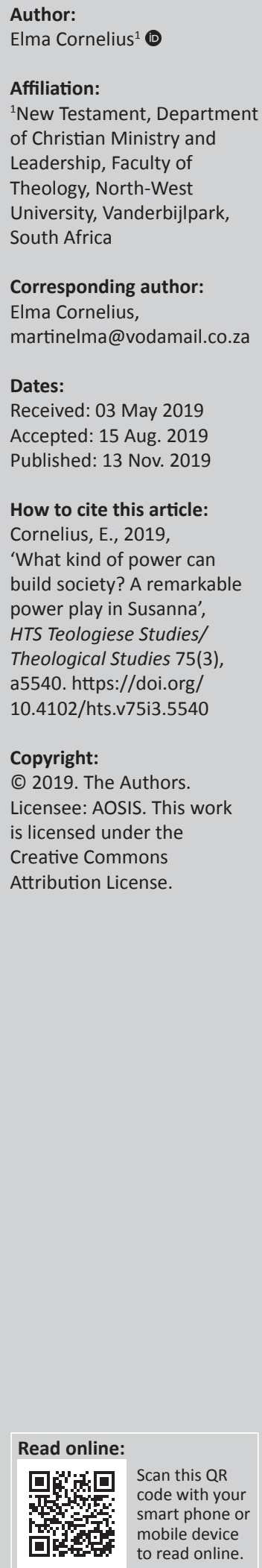

The struggle in Susanna is between the protagonist, Susanna, and the antagonists, namely, the elders. The power struggle between these two groups is the focus of this article. The powers of each are discussed in order to understand the power play. In the end, the power play is between God and evil. It was found that the elders, as men, abused their power by threatening Susanna to have sex with forced consent. In addition, they abused their legal powers to witness against her in court. By contrast, Susanna had no power in public - only limited power as a woman in society and in a marriage. The only power she relied on was her spiritual power because of her faith in God. She trusted God and he protected her by stirring up the spirit of a man named Daniel. Daniel spoke in court on behalf of Susanna. He became an instrument in God's hands. The article concludes with the statement that only spiritual power can save this world.

Keywords: power struggle; antagonist; protagonist; spiritual power.

\section{Introduction}

In the apocrypha Susanna, we read the story of Susanna. As the story goes, the fair Hebrew wife of Joachim, named Susanna, is falsely accused by two elders. As she bathes in her garden, having sent her attendants away, two lustful elders secretly observe the lovely Susanna. When she makes her way back to her house, they accost her, threatening to claim that she was meeting a young man in the garden unless she agrees to have sex with them. Susanna refuses to be blackmailed and is arrested and about to be put to death for promiscuity when the young Daniel interrupts the proceedings, shouting that the elders should be questioned to prevent the death of an innocent. After being separated, the two men are crossexamined about details of what they saw but disagree about the tree under which Susanna supposedly met her lover. The first says they were under a mastic tree ( $(\pi 0$ o $\chi i v o v)$, and the second says they were under an evergreen oak tree ( $\dot{\pi} \pi \mathrm{r} \pi \rho^{\prime}(v o v)$. The great difference in size between a mastic and an oak makes the elders' lie plain to all the observers. The false accusers are put to death, and virtue triumphs. (Wikipidea, https://en.wikipedia.org/wiki/Susanna_(Book_of_Daniel)

The story of Susanna presents us with two categories of characters: the good and the bad people. In narrative criticism, we deal with the protagonist and the antagonist. The protagonist is mostly a good person, who is involved in a struggle with the antagonist, the villain, who opposes the good person. When we read a fiction, or even a mythical story, there is always a constant struggle between the protagonist and the antagonist. In Susanna, we meet the protagonist, Susanna, and the antagonists, namely, the elders. These elders place an obstacle in Susanna's path, which causes her suffering.

Cornelius (2008:103) pointed out that the misuse of power in society is the focus in Susanna. In this article, the focus is on the use and abuse of power by the protagonist, the antagonists and the characters supporting them. The questions that will be answered are the following:

- Was the power seized by the elders because of the authority they had?

- What kind of power did Susanna have?

- What was Daniel's authority and power?

- What was God's role in the power struggle?

- What kind of power is it that will build society, rather than damage society, like the elders damaged Susanna?

The methods to be used are guided by the genre of the text of Susanna, as well as the questions to be answered. As narrative text, Susanna is interpreted with the help of narrative criticism. To address the questions about power use and abuse in an ancient society like the characters in Susanna, socio-historical criticism and psychology are used. 
Firstly, the characters are discussed and then their use and abuse of power are interpreted. Finally, a conclusion is made on what kind of power can build society.

\section{Identifying the protagonist and the antagonist in the narrative}

The protagonist is the leading character, or the main figure, in the story. In the apocrypha Susanna, the beautiful and devout Susanna is the protagonist who is caught in a vortex of struggle because of the antagonists in the narrative. Being continuously presented as a good person, Susanna receives all the sympathy of the readers. Susanna is, therefore, a person with whom readers can easily identify. The antagonists are the opponents of the protagonist. In Susanna, the elders are the antagonists who are seen creating obstacles in Susanna's path.

The confrontation between Susanna and the elders is made possible because of Susanna's husband Joachim, who was a wealthy Jew and lived in a house with a fine garden. The elders, who were appointed as judges, used Joachim's house as their courtroom.

Susanna is forced into a struggle with the authorities caused by the elders. Eventually, the struggle is between Susanna and the elders themselves. This struggle between Susanna and the elders, however, also becomes a struggle between Susanna's God, on the one hand, and the elders and society, on the other hand.

\section{The power struggle}

The power struggle is what makes a story great. It keeps the audience interested in the outcome of the story.

The elders were not antagonists because of strength, but because of authority and power in society. One would normally expect the villain to be the dark lord, the witch, the usurper, the criminal mastermind, the bully, the ancient evil with the intent to harm the protagonist, to take revenge or simply cause chaos, but the elders in Susanna are different.

I would not even call them 'everyday antagonists' who simply act in opposition to Susanna, creating conflict without a distinct goal of setting the world on fire, discouraging Susanna from pursuing a goal they find dangerous or irresponsible, creating emotional or physical roadblocks that hinder her, or stirring up trouble.

The elders fit more into the category of 'immoral entities'. However, they are not the kind of antagonists who specifically aim to harm the protagonist's morality. They fall in the hands of lust and desire and end up giving up their morals. In order to maintain their power in society, they give up their morals and give in to lies and deception.

Susanna fights to hold onto her commitment to God by not submitting to the antagonists' threats. In summary, Susanna's story is all about maintaining power. In the next section, the ways in which different characters use and abuse power are discussed.

\section{Power and authority}

Power is the ability to control others, events or resources, to make happen what one wants to happen in spite of obstacles, resistance or opposition and it can be held, coveted, seized, taken away, lost or stolen (Crossman 25 October 2019) and even misused and abused, I would add.

Authority is always tied to social positions or roles; it is legitimate power (Crossman 29 March 2019) which is sanctioned and institutional (Bierstedt 1964:79).

In this section, the power and authority of the characters is the focus.

\section{The power of the elders}

Susanna 19 tells how the elders ran to Susanna in the garden and admitted their desire for her and tried to negotiate a consenting sexual relationship with her. They immediately blackmailed her by warning her that in case she would not agree, they would testify against her that a young man was with her, and that this was the reason why she sent her maids away ${ }^{1}$. With the threat of accusing her of adultery, the elders no longer asked her consent, but rather demanded sexual intercourse. This was an attempt of rape, although not through physical force, but through the force of blackmail, threat and intimidation.

Why did the elders try to rape Susanna? Did they have authority? If they had authority, the next question will be, authority in which circles? Did they have power? If they had power, was it a result of their gender, age or authority?

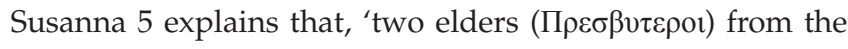
people were appointed as judges (Kpı $\left.\boldsymbol{K}^{\prime}\right)^{\prime}$.

Susanna 6 proceeds: 'they were frequently at Joachim's house, and all who had a case to be tried came to them there'. These two men had the legal authority of judges who exercised judgement. They had authority to makejudgements. Susanna 5 says that they were $\alpha \pi \varepsilon \delta \varepsilon \imath \chi \theta \eta \sigma \alpha v$ 'appointed'. These two men thus had legitimate power and the social positions of judges in society.

In ancient societies, the elders were adult men, usually older, who were responsible for making decisions in a local village or community. In the Old Testament, in Exodus 3:16, 24, Numbers 11 and Proverbs 31:23, we read about the elders in society - men who led in local decision-making. It is clear from these, and other biblical passages, that elders held a place of leadership from an early period. Over time,

1.Susanna 17-18 tell how Susanna ordered her maids to bring her oil and washing balls and to shut the garden doors. The maids then left as commanded. The elders threatened to use this against her as an excuse to meet with the young man. 
the position of elder progressed from an informal position of leadership to a specific calling from God.

The elders were charged with the responsibility of judging the people on civil matters and thus they served as local magistrates in bringing murderers to trial (Dt 19:12, 21:1; Jos 20:4), punishing a disobedient son (Dt 21:19), inflicting penalty for slander (Dt 22:15), for non-compliance with the Levirate marriage law (Dt 25:7), enforcing the law (Dt 27:1) and conducting the service in expiation of unwitting violation of the law ( $\operatorname{Lv} 4: 13)$.

Elders were also used by Moses to communicate to the people (Ex 19:7; Dt 31:9) and to administer the law of God. The elders would also lead in the observation of the Passover (Ex 12:21), and perhaps other elements of worship. Later, the elders of Israel were specifically involved in the leadership of cities (1 Sm 11:3, 16:4 and 30:26). Still, their function was decisionmaking - applying wisdom to the lives of the people in resolving conflicts, giving direction and generally overseeing the details of an orderly society of God's people.

As we read in Proverbs 31:23, we can see that the elder was a respected and honoured person in society. The elders in Susanna's story were honourable men because of their authority as judges.

These elders thus had a form of 'referent power' (see Van Vliet 2010) as they were regarded to be role models in society, they had much influence, they were highly liked and there is even a possibility that people identified with them.

The question is, 'why did the elders want to rape Susanna?' And what is the psychological nature of this rape attempt? Groth and Burgess (1977:403-404) identify two types of rape: anger rape and power rape. These elders did not commit an anger rape by violently attacking Susanna and forcing her into having sex with them. It does not exclude the possibility, however, that they could have done that if Susanna did not call out for help. But they committed a power rape where they planned the attack in order to gain pleasure from meeting their lust. These two men abused their power in society as men by approaching Susanna and asking her consent for sexual intercourse.

Jordaan and Chang (2018) say that 'evil and lawlessness penetrated into' the elders' minds. One may ask whether these elders planned a pleasure trip or a power trip with Susanna? Was sexual fulfilment the motive for their request or was it rather a desire to dominate Susanna? Tedeschi and Felson (1994:131) are of the opinion that rape is more about sexual fulfilment than power and I believe in this case it is indeed true.

These two men were, as males and elders, in the most powerful position in this scenario; however, they had no defence against the powerless woman's power of beauty. Susanna 9-11 narrates that the elders 'suppressed their consciences and turned away their eyes from looking to Heaven or remembering their duty to administer justice'. They had sexual fantasies and the power of their sexual desire became stronger than the power of their religion and stronger than the power of their positions in society. The power of a woman's beauty leads to a power of desire within them and they were willing to turn their backs on God, to depart from their moral values, and to forsake their duties as judges between right and wrong. They were driven by a sexual desire to become crooked and pervert and wicked.

The moment the elders confessed their lust to each other (Susanna 14), peer pressure became another power in their actions. Susanna 14 says that they confessed their lust and then together they arranged for a time when they could find her alone. They agreed to support one another in their evil endeavour and then there was no turning point left. In psychology, rape is a forcible sexual assault - a sexual offense (Groth \& Burgess 1977:400). Groth and Burgess (1977:401) state that rape has yet to be regarded as a sexual deviation. They refer to rape cases such as paedophilia, exhibitionism, nymphomania and group sex as examples of sexual deviation. The context of the attempted rape in Susanna can thus be seen as a sexual deviation where two men plan to have sexual intercourse with one woman. The planned group sex of the elders increased the individuals' power and I think that the elders were inspired to go through with their plans the moment they agreed to group sex.

When Susanna refused to 'lie down' with these men, she called out for help (Sus 24) and the elders knew that they had to make a plan. They shouted against her and opened the doors of the garden to allow people in. Susanna 26-27 explains how the elders then told their lies to the people as planned.

Then the elders used 'coercive power' (Van Vliet 2010). They tried to force Susanna to do something against her will. They used their initial referent power to threaten her. During the trial, the two men who tried to rape Susanna acted as witnesses and testified about her (Sus 36-41) that:

- while they were walking in the garden alone, Susanna came in with two maids, shut the garden doors and dismissed the maids

- a young man then, who was hiding there, came to her and lay with her

- they were in a corner of the garden, and when they saw that wickedness - Susanna and the young man embracing - they ran to them

- they could not hold the man because he was stronger than them, and he opened the doors and got away

- they seized Susanna and asked who the young man was, but she would not tell them.

These elders abused their power as authoritative judges in society by their twisting of justice. They knew no one would question their motives. Because they were elders of the people and judges, the assembly ( $\sigma v v \alpha \gamma \omega \gamma \eta)$ believed them 
and condemned her to death. Because they had status, authority and power in society, they were believed. Being a woman, Susanna had no social power to defend herself in the court.

These elders tried to rape Susanna because of them turning away from God and becoming desirous for her.

It would imply that power abuse is in this case an act of turning away from God and a turning away from morals.

Jordaan and Chang (2018) also brought up the issue of space. I think power abuse is always a case of penetrating a space where one has no authority. Power abuse is also a case of being overwhelmed by something like desire in this case.

\section{Did Susanna have power in society?}

Susanna is portrayed as a woman with beauty and piety. Kanonge (2013:2) shows us the irony in this description, as beauty entailed sexual temptation as it was a potential threat in ancient societies to men's piety. In this line of thought, Kanonge (2013) argues that Susanna's godliness and fear of God are ironically combined with her beauty. One can immediately sense a power play between two major powers, namely, sexual temptation and a life dedicated to God. I think the author deliberately introduced the story with this description of Susanna in order to make the readers aware of the ingredients for a possible power struggle.

Sered and Cooper (1996:44-45) show that Susanna, at first, seems to be a powerful person. She had personal servants and she ordered them to do chores for her (Sus 15-17). Cornelius (2008:99) shows that the wealth actually belonged to her husband - materially she was poor like all women in ancient society. As a Jewish woman, she was restricted in a patriarchal world. Ferguson (1987:58) states that the Jewish woman was the mistress of the home, not as restricted in public appearance as Greek women, but they could not testify in court. Her duties were to educate the children, to grind flour, cook, do laundry, make beds and spin wool. It was indeed her husband's responsibility to provide for her. That is why we read in Susanna that her husband provided for her. The storyline, however, gives one the impression that Susanna was even more spoiled by her many maids. Structurally, she was powerless as she was just another possession of her husband Joachim (Cornelius 2008:99).

While the elders were waiting for an opportunity to rape Susanna, Susanna planned to take a bath outside in the garden because it 'was a hot day' (Sus 15). They brought her olive oil and ointments and shut the garden doors once they left, as ordered by Susanna (Sus 18). One cannot but wonder whether this was perhaps an attempt to seduce somebody? Why would Susanna take a bath outside in the garden?

No traces of bathrooms have been found in old Hebrew houses, even in royal palaces (Orr 1915). Orr (1915) is of the opinion that where Joachim had a bathing pool in his garden in Babylonia (Sus 15), Susanna might refer simply to bathing in the open air, as the public plunge baths of the Greek type were unknown amongst the Hebrews until they were brought in contact with the Greek civilisation. It was said, however, at the very beginning of the story that Joachim was wealthy, with a garden adjoining his house (Sus 4) and that the house was so big that even the judges could use it as a courtroom (Sus 6). It seems fair, therefore, to believe that Joachim could have had a bath pool in his garden. The story gives the impression that Susanna had no ulterior motives other than simply bathing for refreshment on a hot day.

What gave Susanna ultimate power, however, was her strong faith in God. This is moral and spiritual power.

Susanna was a model of faith in God. She is described as a God-fearing woman (Sus 1) who remained steadfast in her beliefs, depended on God and prayed to God (Sus 23, 42-43). And when God saved her form execution, it proved that spiritual power triumphed over the corruption and misuse of the social power of the elders. Cornelius (2008:99) says Susanna stood out as a morally strong woman who stayed true to her God (Sus 23, 2-43). Her faith empowered her to go on in life.

What is interesting about Susanna's spiritual power is that to be able to get access to a spiritual power, Susanna had to give up her own power over her own life. That is what spiritual power is all about. She handed her life over to God in faith and, in return, received an immense spiritual power from a God who is in control of everything and everyone. Faith, thus, empowers human beings.

Once Susanna appeared in court, she remained within the prescribed roles of patriarchy, kept quiet and did not dare to defend herself (see Ferguson 1987:58). She fulfilled the typical role of a Jewish woman in that society with no power at all. Because of her spiritual power, however, a man called Daniel played an important role in Susanna's struggle in court and spoke on her behalf. It is, therefore, worthwhile to study Daniel's power.

\section{The power of Daniel}

Daniel is introduced in the story as a mere young boy with no expertise in judicial affairs (Sus 45). Susanna turned to God in her dark hour and 'the Lord heard her cry' (Sus 44). Verse 45 proceeds with, 'God stirred up the holy spirit of a young lad named Daniel'. God answered Susanna's prayers by inspiring and empowering Daniel to step forward for Susanna. Daniel was sent by God to intervene.

Daniel stepped forward and 'shouted with a loud voice: I want no part in shedding this woman's blood' (Sus 46). The fact that Daniel was willing to step forward to stop wickedness and a morally wrong act, to stop a society from allowing false testimonies and condemning innocent people, proved him to be a virtuous young man. The other elders immediately acknowledged him as an elder or judge (Sus 50). This gave Daniel the authority to take over the examination and he used this legal power to prove to the court that Susanna was innocent. 
The whole assembly was persuaded by Daniel and they automatically acknowledged his defence and intervention as an act of God when they 'raised a great shout and blessed God' (Sus 60). The story proceeds with a remark that from that day onward 'Daniel had a great reputation among the people' (Sus 64). Because of Daniel's role in Susanna's court case, he kept his social power as man of God and a wise judge.

As God was the One to whom Susanna reached out, and as God was the One who empowered Daniel to react, it is important to focus for a while on the power of God in this story.

\section{The power of God}

The story mentions how God reacted to Susanna's prayers. It is said that God 'heard' her (Sus 44), that he 'stirred up' Daniel's spirit (Sus 45). Susanna had the spiritual power to trust in God and God intervened on her behalf. Cornelius (2008:106) shows that in Susanna, 'God can change situations'. God has the almighty power to intervene when he wants to. Susanna concludes with the remark in verse 60 that the assembly realised that God 'saves those who hope in Him'. This supernatural power showed in the story of Susanna that he will not allow injustice to have the last word against those who are faithful to him and that he will intervene on their behalf.

\section{Conclusion}

The one who held onto her God as the higher power could survive the onslaught of evil. A spiritual power is offered in this story as the only power that can help mankind to survive. The legal powers of people can be corrupted. The immense power of natural sexual desires can be harmful. In this story, the protagonist could be saved from the power of natural desires and group pressure because of a moral and spiritual power - a trust in a higher power. In a modern world where we all face the power of corruption, the power of crime and the abuse of legal power, the message of Susanna is to cling onto spiritual power.

\section{Acknowledgements Competing interests}

The author has declared that no competing interest exist.

\section{Author(s) contributions}

I declare that I am the sole author of this research article.

\section{Ethical consideration}

This article followed all ethical standards for a research without direct contact with human or animal subjects.

\section{Funding information}

This research received no specific grant from any funding agency in the public, commercial, or not-for-profit sectors.

\section{Data availability statement}

Data sharing is not applicable to this article as no new data were created or analysed in this study.

\section{Disclaimer}

The views and opinions expressed in this article are those of the authors and do not necessarily reflect the official policy or position of any affiliated agency of the authors.

\section{References}

Bierstedt, R., 1964, 'The problem of authority', in M. Berger \& T. Abel (eds.), Freedom and control in Modern Society, pp. 67-81, Octagon Books, New York.

Chaignot, M.J., n.d., 'Daniel and Susanna', BibleWise, viewed 02 April 2019, from www.biblewise.com/bible_study/apocrypha/daniel-and-susanna.php.

Clanton, D.W., 2006, The good, the bold, and the beautiful: The story of Susanna and its renaissance interpretations, T\&T Clark, New York.

Cornelius, E.M., 2008, 'The woman in "Susanna." An understanding of the rhetoric of "Susanna"', Acta Patristica et Byzantina 19(2008), 97-109. https://doi.org/10.108 0/10226486.2008.11745789

Cornelius, E.M., 2009, 'Thecla and Susanna as heroes, martyrs and saints', Ekklesiastikos Pharos 91(1), 1-11.

Crossman, A., 2019, Power definitions and exmaples in sociology, viewed 06 November 2019, from https://www.thoughtco.com/power-p2-3026460.

Crossman, A., 2019, Authority, viewed 06 November 2019, from https://www. thoughtco.com/power-p2-3026460.

Ferguson, E., 1987, Backgrounds of early Christianity, William B. Eerdmans Company, Grand Rapids, MI.

Groth, N.A. \& Burgess, A.W., 1977, 'Rape as sexual deviation, American Journal of Orthopsychiatry 47(3), 400-406. https://doi.org/10.1111/j.1939-0025.1977.tb01246.x

Halpern-Amaru, B., 1996, 'The Journey of Susanna among the Church Fathers', in E. Spolsky (ed.), The judgement of Susanna: Authority and witness. Society of Biblical Literature Early Judaism and its literature 11, pp. 21-34, Scholars Press, Atlanta, GA.

Jordaan, P.J. \& Chang, C., 2018, 'Penetration of private places in Theodotian Susanna', HTS Teologiese Studies/Theological Studies 74(3), a5004. https://doi.org/10.4102/ hts.v74i3.5004

Kanonge, D.M., 2013, 'Thematic irony in the story of Susanna, HTS Teologiese Studies/ Theological Studies 69(1), Art.\#1255, 6 pages. https://doi.org/10.4102.hts. v69i1.1255

Orr, J., (ed.), 1915, 'Definition for "BATH; BATHING"', International Standard Bible Encyclopedia, viewed 23 February 2019, from bible-history.com - ISBE.

Sered, S. \& Cooper, S., 1996, 'Sexuality and social control: Anthropological reflections on the Book of Susanna', in E. Spolsky (ed.), The Judgement of Susanna: Authority and witness. Society of Biblical Literature Early Judaism and its Literature 11, pp. 43-55, Scholars Press, Atlanta, GA.

Tedeschi, J. \& Felson, R., 1994, Violence, aggression and coercive actions: A social interactionist perspective, American Psychological Association, Washington, DC.

Van Vliet, V., 2010, 'Five forms of power (French and Raven)', ToolsHero, viewed 08 April 2019, from https://www.toolshero.com/leadership/five-forms-of-pwerfrech-raven/.

Wikipidea, viewed 04 September 2019, from https://en.wikipedia.org/wiki/Susanna_ (Book_of_Daniel). 